\title{
A multi-method approach to explore environmental governance: a case study of a large, densely populated dry forest region of the neotropics
}

\author{
Marianna Siegmund-Schultze ${ }^{1,2}$ (D)
}

Received: 18 September 2018 / Accepted: 5 February 2020 / Published online: 25 February 2020

(c) The Author(s) 2020

\begin{abstract}
Semiarid regions are often secondary on the national to global (scientific) agenda, especially if abundant vegetation elsewhere draws attention and the local population is considered backwards thinking and poverty-stricken. The Caatinga, our case study, is such a region, home to millions of Brazilians and a vast biodiversity. Unfortunately, a widely uncoordinated land use change and biodiversity decline are happening, while farmers' livelihoods are at risk. We hypothesize substantial weaknesses in the current governance practices. To explore governance of the less noticed region, we conducted interviews and field visits and complemented the findings with the literature and internet resources. Our multi-method approach combines the social-ecological systems framework with constellation analysis and dynamic modeling. The aim was to understand the current state of governance in the region and identify clues for more sustainable land management. The use and conservation of Caatinga are negotiated at multiple levels, which are only sporadically interlinked. The conversion of forest land into alternative land uses shifts and shares responsibility among different sectors, while cross-sectoral cooperation is rarely observed. The region and its population face massive prejudices. Obstructing attitudes, such as thinking in dichotomies, and paternalistic and opportunistic approaches, are being addressed by some new coalitions taking alternative action. It is unlikely that these isolated initiatives will converge by themselves to a larger transformation toward sustainable resource use. There is a need to bring the dispersed actions in a more focused and coordinated approach, integrating socioeconomic and ecological concerns, values, and partnerships.
\end{abstract}

Keywords Land use change $\cdot$ Multi-level governance $\cdot$ Social-ecological systems $\cdot$ System dynamics $\cdot$ Constellation analysis $\cdot$ Caatinga

Marianna Siegmund-Schultze

marianna.siegmund-schultze@wur.nl

1 Environmental Assessment and Planning Research Group, Berlin Institute of Technology (TU Berlin), Straße des 17. Juni 145, 10623 Berlin, Germany

2 Agrosystems Research, Wageningen University \& Research, P.O. Box 16, 6700 AA Wageningen, The Netherlands 


\section{Introduction}

The Brazilian Federal Constitution states that all citizens shall benefit from an ecologically balanced environment (Brazil 1988, article 225). Paragraph 4 of the same article specifies the biomes that are considered national patrimony: the Amazonian Forest, the Atlantic Forest, the Serra do Mar, the Mato Grosso Pantanal, and the Coastal Zone. The Caatinga is not included even though it is a large, unique and valuable ecosystem. Nevertheless, article 23 establishes that the government (at the municipal, state and national levels) shall protect the environment, combat pollution, and preserve forests, fauna and flora. Several federal acts are concerned with sustainable development (e.g., the Forest Code, Brazil 2012).

The Caatinga is entirely Brazilian with a specific floral and faunal biodiversity (Santos et al. 2011). In the past decades, studies on Caatinga issues in the natural sciences increased somewhat (de Albuquerque et al. 2012). Nevertheless, the biome, a seasonally dry tropical forest, still receives little attention in comparison to other more prominent Brazilian biomes, such as the Amazon (Santos et al. 2011). Open habitats, as opposed to dense forest, are often overlooked, such as the Chaco with its native grasslands that host abundant, adapted species (Grau et al. 2015). Characterized seasonally by water scarcity and low vegetation biomass, the Caatinga is home to a complex, heterogeneous mosaic of vegetative formations, threatened by anthropogenic disturbance (Maciel et al. 2012). As one result, larger wildlife, such as deer, has diminished sharply over time (de Albuquerque et al. 2012).

An increasing net loss of Caatinga land cover was detected for the period from 1990 to 2010 (Beuchle et al. 2015). The annual net rate of cover loss was estimated to be $-0.19 \%$ for the period 1990 to 2000 and $-0.44 \%$ from 2000 to 2010 . The total net cover with natural vegetation in the Caatinga area was about $63 \%$ in 2010, down from $67 \%$ in 1990 . The aggregated values mask local disparities. For instance, Schulz et al. (2017) found considerable net gains in woody vegetation, in particular, in the central São Francisco River section, while this area also showed high risks for land degradation and desertification. Such risks partly stem from the rather high population pressure of 28 persons per $\mathrm{km}^{2}$ in the Caatinga region (IBGE 2019). The values for the Cerrado and the Amazon are lower with 16 and 4 persons per $\mathrm{km}^{2}$, respectively.

Just $6.4 \%$ of the biome was officially protected in 2008, and in many cases just nominally, since the compulsory management plans were widely lacking (Maciel 2010). Ten years later, the number is $8.8 \%$ (excluding superposition) (MMA 2018). This is overall still less than the $10 \%$ planned to be achieved already in 2010 by the Brazilian Federal Ministry of the Environment (MMA), respectively, 17\% in 2020 in line with the United Nation's Aichi-target 11. Dwellers invade compulsory private conservation areas, socalled legal reserves (reserva legal) (PETCON 2010), which consequently become ever more fragmented and less conserved. Land degradation, deforestation, and land use change are occurring at a high pace (Beuchle et al. 2015). Dichotomous thinking, which declares objectives as mutually exclusive or assigns fixed roles (e.g., conservation vs production, land sparing vs land sharing), limits our understanding of the intertwined and nonlinear effects and gradients of biodiversity, land use, and productivity interactions (Seppelt et al. 2016). Already back in 2005, Leal et al. called for a new conservation strategy which better limits the degradation of habitats and ultimately halts desertification, preserves ecosystem services, and promotes sustainable use of the natural resources.

Several sectors are part of the depicted nexus: overall land use planning, biodiversity and habitat conservation, forestry, agriculture, to a certain extent fisheries, mining 
and other industries, energy, tourism, and urbanization along with transportation. The recent change in the Brazilian Forest Code (Brazil 2012) has severe impacts on land use and ecosystem services, as exemplified for the Atlantic Southern Forest (Alarcon et al. 2015), in particular: the reduction in restoration targets on hilltops, slopes, and along water bodies threatens sediment retention and biodiversity conservation. In order to be successful, strategic planning, increasingly a component of protected areas' management plans, needs to be complemented by improvements in the proper use of the planning tools, capacity building, and motivation of the people involved (Barreto and Drummond 2017). The specific governance arena of Caatinga is currently rather silent. Existing coalitions appear to be weak. What happened? Which factors affect the current scenario of apparently unsustainable Caatinga use? Which levers are promising to reverse this scenario? How can the competing interests of destructive uses, sustainable uses and conservation be reconciled?

One could argue that a mosaic of different uses is appropriate for a huge biome. Only commercial production or conservation purists might disapprove of this statement. However, the ongoing land use changes and degradation raise concerns of local activists and other civil society stakeholders, as well as parts of national governments through global commitments, such as achieving land degradation neutrality. In the national perception, the Caatinga region is still equated with backwardness, poverty, and recurrent disaster. The cultural construct of "the Northeast," which largely coincides with the Caatinga region, emerged in the 1920s, based on institutionalized relief measures for the population affected by drought and in an attempt to preserve privileges of the political elite (Albuquerque Júnior 2004).

Arguments for conserving Caatinga are, above all, environmental. They comprise public good ecosystem services (see Falk et al. 2018), such as the gene pool, carbon sequestration, and water provision and purification through infiltration that relies on an adequate land cover. The Caatinga is also seen as a "natural laboratory for the study of how plants, invertebrates, and vertebrates adapt to highly variable and stressful moisture regimes" (Leal et al. 2005). This view also embraces the bequest value: potential uses in the near or distant future, requiring its conservation today. Cultural ecosystem services are sacred forest sections (de Albuquerque et al. 2011), specific endemic trees considered sacred, e.g., as summarized for the umbuzeiro tree (Rodorff et al. 2018), and ultimately the landscape's beauty (Vieira et al. 2018).

Several provisioning ecosystem services can be best enjoyed when Caatinga vegetation is standing, such as medicinal plants; others, e.g., fuelwood or fodder, can be harvested in a destructive or sustainable way, while crop production (provision of crops) is mostly bound to the prior destruction of Caatinga stands. Eventually, the conservation of Caatinga has two main connotations, relating to Caatinga species conservation or Caatinga stands conservation. Moreover, Caatinga as a biome plays a role in the wider network of areas where large animals can strive, for instance, the jaguar, and the necessary corridors which connect such areas. The corridors analyzed in the Caatinga belong, however, to the most disturbed ones, since they are heavily fragmented (Silveira et al. 2014). So far, the unsustainability of Caatinga is prevailing, while a sustainable scenario would involve better compliance with environmental law, mainstreamed environmental education, and sustainable land management practices (Falk et al. 2018).

We hypothesize that the various organizations and individuals, under current institutions and beliefs, govern the Caatinga biome in an uncoordinated manner, which facilitates its widely uncontrolled land use change. In an exploratory approach, we characterize the natural and economic environment of the Caatinga case and analyze its governance setting and 
practices. Starting at the federal biome level, we use Pernambuco as a state example and focus on concrete conservation efforts at the municipality level in Floresta (Pernambuco).

\section{Methods}

We conducted an exploratory study on the characteristics of environmental governance of the Caatinga region. Figure 1 (small map) shows the location of the biome in Brazil. The potential area covered by Caatinga is $844,453 \mathrm{~km}^{2}$, which corresponds to roughly $10 \%$ of Brazil's land surface (IBGE 2004). The dry forest, a xeric shrubland, is far from being homogenous, and this is why scholars suggest using its plural term: Caatingas (Lima 1996; Sampaio 2010). Climatic patterns, geology, and soil conditions determine, together with human impact, current Caatinga variation. The multi-dimensional description of the study region is an essential part of the results chapter, which synthesizes knowledge from the literature and own primary data. The multi-level governance system was studied with a focus on Pernambuco at state level and Floresta at municipality level. Pernambuco covers $98,076 \mathrm{~km}^{2}$ with an estimated population in 2018 of 9,496,294 (89.62 inhabitants per $\mathrm{km}^{2}$ ), and a human development index (HDI) of 0.673; the corresponding figures for Floresta are $3,644 \mathrm{~km}^{2}, 32,556$ people (8.04 per $\mathrm{km}^{2}$ ), and an HDI of 0.626 (IBGE 2018). This selection follows the logic of the comprehensive, collaborative project on sustainable land management in which the study was conducted (see Siegmund-Schultze et al. 2018a, b).

Following the work by Turnheim et al. (2015), we combined three analytical approaches, which follow different rationales. We applied the social-ecological system (SES) framework, system dynamics, and constellation analysis to study preconditions, barriers, and opportunities for transition toward sustainable land use and conservation. The analyses are based on the fieldwork from a 5-year collaborative project (2012-2017), including observation during field stays, workshops on partial research results, and in-depth as well as informal interviews with stakeholders. Moreover, literature and Internet resources, such as governmental reporting and blogs, are another key component. The participants of this study are key stakeholders in Caatinga governance or are knowledgeable about it: representatives from civil society (6), private sector (5), and governmental organizations (5). The interviews were oriented toward the specific role and experience of each respondent, motivation for dealing with Caatinga issues and assessment of options and barriers to sustainable use and conservation of Caatinga.

The SES framework was used to scrutinize Caatinga as a social-ecological system. The framework has been employed earlier to study a broad range of complex issues in coupled human-nature systems. Among those issues are: classifying the governance processes and outcomes of small-scale fisheries (Basurto et al. 2013), understanding perceptions of justice in the institutional design of fisheries (Barnett and Eakin 2015), measuring ecosystem services (Reyers et al. 2013), operationalizing land degradation neutrality (Okpara et al. 2018), analyzing the co-management of protected areas (Williams and Tai 2016) and enhancing complexity thinking (Rogers et al. 2013). The SES framework essentially provides a checklist in a tiered approach, which is continuously updated by various scientists, and which is used to systematically and comparably capture systems in their context. The list's compartments encompass the social, economic, and political settings, the resource systems, the resource units, the users or actors, the governance systems, the related ecosystems, and finally the focal action situation (Ostrom 2009; McGinnis and Ostrom 2014). 
Data sources: http://mapas.mma.gov.br/ i3geo/datadownload.htm, http://maps.lapig.iesa.ufg.br/lapig.html. EPSG: 4674 - Sirkas 2000. QGIS. Data from 07/2018: protected areas; 04/2018: geological sites, geoparks, hydropower and solar plants, wind parks; 2015: quilombos; 2010: indigenous.

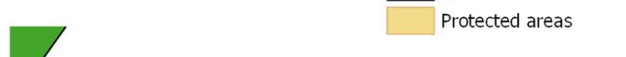

Legend: Brazil
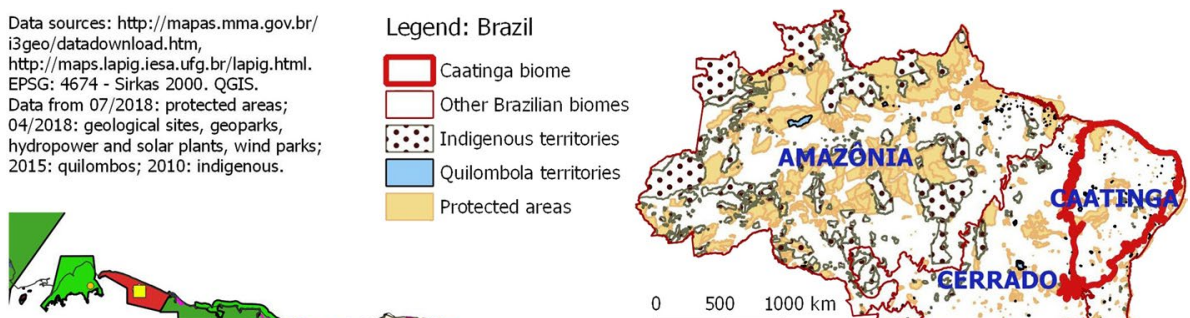<smiles>[CH]1CC1</smiles><smiles>CCCCC1CCC1</smiles>
MARANHAO
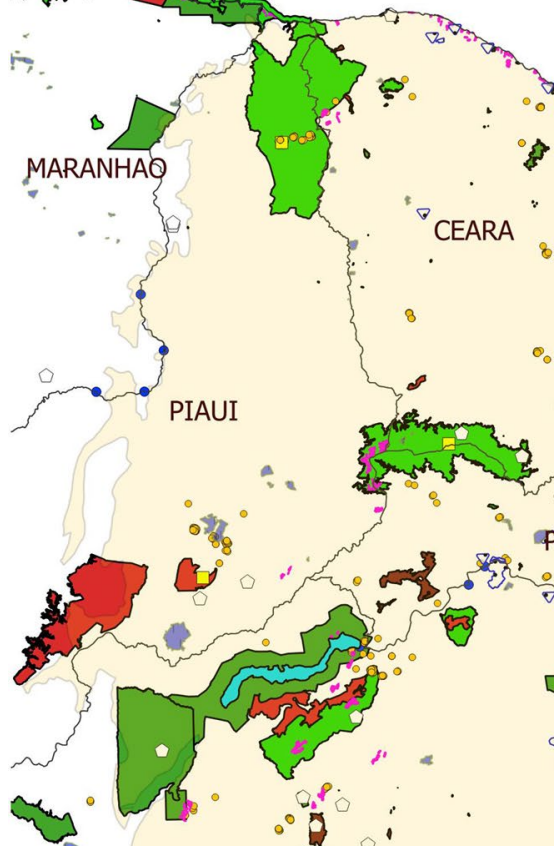
RIO GRANDE DO NORTE

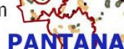

GERADO \{

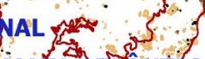
MATA A I LANUICA $5 \cdot 12$ mAMP AMP $A$ egend: Caatinga

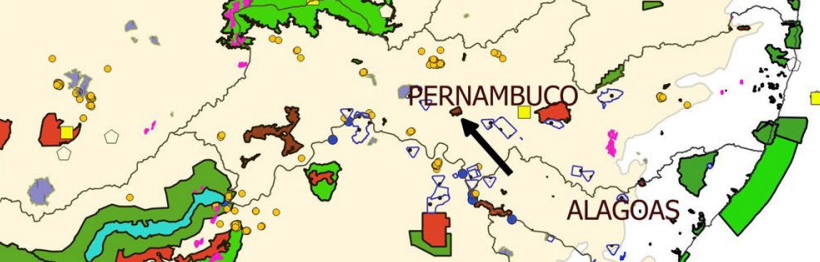

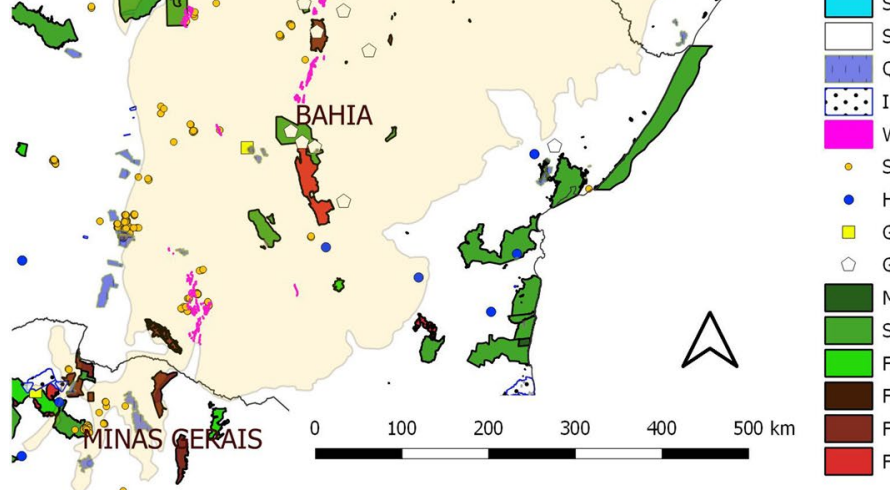

Caatinga biome Sobradinho reservoir States Quilombola territories Indigenous territories Wind parks Solar plants

Hydropower plants Geoparks Geological sites Municipal protected area, sust. use State prot. area, sustainable use Federal protected area, sust. use Fully protected municipal area Fully protected state area

Fully protected federal area

Fig. 1 Caatinga as one of the Brazilian biomes and their protected areas (small map), and a focus on the Caatinga region with protected areas by administrative level, traditional community land, and the recently booming energy landscapes (large map). The arrow indicates the location of the Serra da Canoa, a fully protected state area 
The list is non-binding; the scientists choose from it what appears to be the most suitable in their context. The action situation studied here was defined as the loss of vegetation cover.

A conceptual diagram of a system dynamics model, created in Stella software, served to enhance the understanding of vegetation cover loss in Caatinga, focusing on its drivers of land use change and land degradation. A basic tool in systems thinking is the linking of factors based on their elementary relationships (Zhang et al. 2016). Conceptual modeling does not depend on data; instead, it draws attention to essential concepts (Givens et al. 2018). Basic stock and flow diagrams consist of stocks, the key resources, flows, the directed interrelationships between the stocks or into and off the system, and usually at least one converter that mediates changes over time. The aim here was to visualize causal relationships, while keeping the diagram as simple as possible. We used only two stocks, natural and disturbed Caatinga, and focused on the actions and processes that convert Caatinga from a natural to a disturbed state. Those converters display the manifold pressures on the Caatinga stands and highlight options for adjusting the management. Following Nabavi et al. (2017), we explicitly used variables from different disciplines.

Finally, a constellation analysis was performed about "initiative-based learning" (Turnheim et al. 2015). At the center was the local engagement and conflicts in the transition toward a functional protected area, i.e., the ecological station Serra da Canoa in Floresta municipality, which is located $450 \mathrm{~km}$ from the state capital Recife (Pernambuco). The constellation is based on online resources about the station's making and information from discussions with key stakeholders. The analytical procedure consists of assembling elements of the situation in question. These are from four categories: actors, regulations and concepts, natural components, and technical objects. Subsequently, the identified elements are arranged according to their proximities or antagonisms, additionally evidenced by showing the type of their interrelationships, e.g., neutral, conflictive, directed, missing or unclear (Schäfer and Kröger 2016). Constellation analysis can be used as a conceptual and systematic structuring mechanism (Siegmund-Schultze et al. 2015), likewise in this study. The analysis can also be used in a transdisciplinary approach to initiate discussions between stakeholders and ultimately develop a shared perspective of different stakeholders (Rodorff et al. 2013; Mahlkow and Donner 2017). The visualization process leads to discovering conflicts and options for action.

\section{Status and prospects of the Caatinga and its region}

\subsection{The natural environment and conservation areas}

The Caatinga hosts several endemic vegetation species that are emblematic ("Appendix 1": resource units [RU] and related ecosystem [ECO]). According to species group, endemism varies between 7 and 57\% (Leal et al. 2005). Since the climatic region is warm but semiarid, the vegetation is rather sparse (Fig. 2) and displays particular adaptation features to temporary water scarcity and heat. By contrast, mammals of the Caatinga do not show physiological adaptations, but show behavioral adaptations (de Albuquerque et al. 2012). The largest protected areas in Brazil, also measured as a percentage of land use (namely 28\%), are in the Amazon. The percentages of the Cerrado and Caatinga are $8.3 \%$ and $8.8 \%$, respectively, in 2018. In the Amazon region, other major conserved areas are the indigenous territories-as shown in Fig. 1, small map. Indigenous areas (data from 2010) cover more than 20\% in the Amazon and about 5\% 

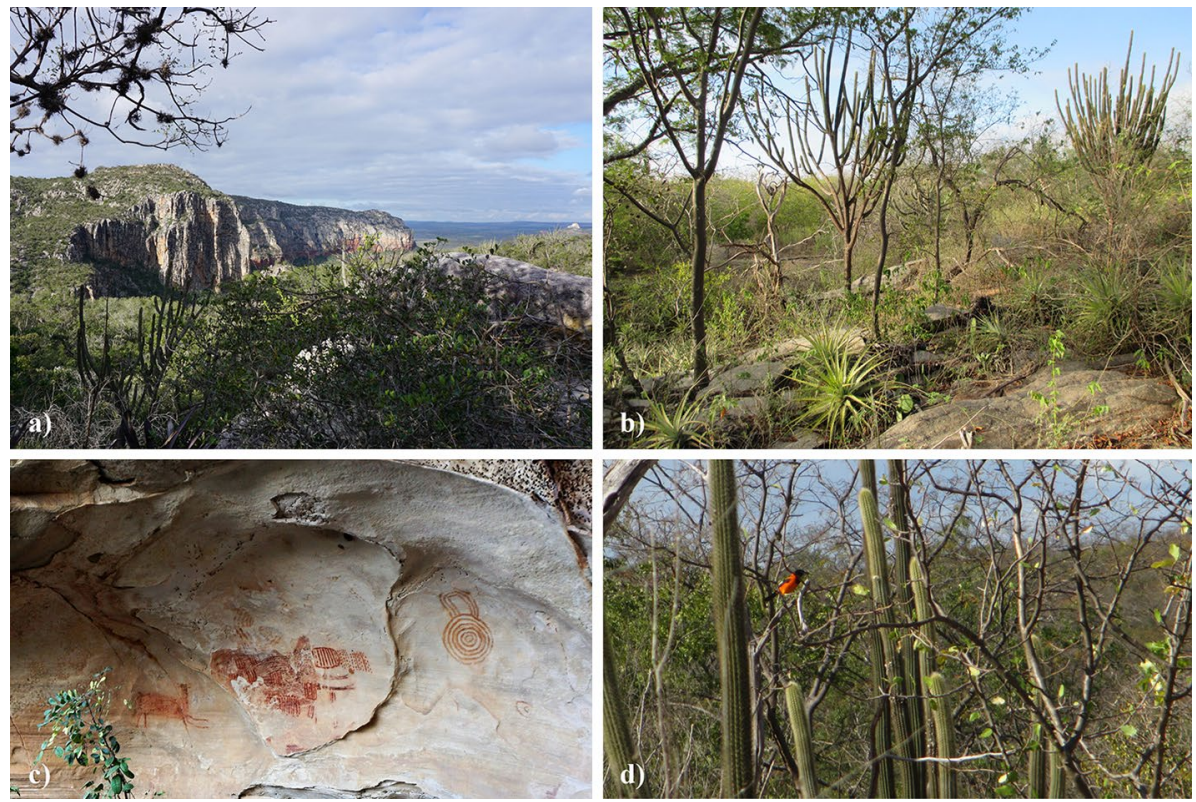

Fig. 2 Impressions of the Caatinga: a landscape of the Catimbau national park, b sparse vegetation in the ecological station Serra da Canoa, c rock paintings in the Catimbau national park, d some birds are threatened to be captured as pets

in the Cerrado. Indigenous territories in the Caatinga are very small, covering only $0.004 \%$. They are not conservation areas per se, and specific risks such as cropping on fragile areas may occur (Grecchi et al. 2014), but the propensity to keep large areas of standing Caatinga vegetation in at least a semi-natural state is high, as for instance evidenced for sacred forest (de Albuquerque et al. 2011).

The focus on the Caatinga biome (Fig. 1, large map) shows a few larger protected areas. There is a cluster of large protected areas in northern Bahia, partly very recently established. However, not all protected areas are conserving the most representative landscapes of Caatinga, but rather unique cases, such as a state protected area (with sustainable use) around the anthropogenic Sobradinho reservoir. Almost in the center of the Caatinga biome, a federal national park on a hill plateau features tropical forest from the Mata Atlântica biome and Cerrado vegetation. It was the first national park at a federal level in Brazil, created in 1946, and is vital for local hydrology. Another large federal unit in the northeastern section of the biome is likewise characterized by isolated vegetation of other biomes.

The remainder of the protected areas is mostly small. Municipal and private conservation areas are almost invisible at the scale of the map, although they are highly relevant at the very local scale. The same holds true for the recognized quilombos (communities of fugitive slaves' descendants) and the many indigenous territories, for instance, those along the São Francisco River, which builds the border of Pernambuco and Bahia, and Alagoas and Sergipe, respectively. The map also features the recently fast advancing energy sector. The hydropower plants in the São Francisco River date from the last decades, while the solar and particularly the wind power industry has gained more visibility over the last few years. Livestock and crop farming, which use much larger space on the ground, are not displayed on the map. 
Quantifying current land use would be an entire study in itself. One difficulty in getting a clear vision of land use quantities is the overlap of several forest-related categories and hence their authorities. The notion of "public forest," which is employed by the Brazilian Forest Service (SFB), includes protected areas at municipal, state, and federal level (ICMBio and MMA as their highest authorities), the indigenous territories (registered by FUNAI), and rural resettlements (run by INCRA), as well as military areas, and thus far undefined areas with regard to their use destination. In practice, the public forest area (according to SFB shapefiles) does not include all such conservation areas. Further, different types of areas can be superimposed; some protected areas overlap with indigenous territories, as shown in Fig. 1. Data about agricultural land use dates from the last census in 2006, while the new census was in progress in 2018 (time of writing). In parallel, the new rural environmental registry was under way (CAR by its Brazilian acronym, a novel instrument of the Forest Code). Discontinued access to data is another constraint. For instance, the official databank about protected areas of ICMBio was interrupted for a period of several months in 2018. Updates to the various registries occur, though at different time intervals, and employ different delimitations of the Caatinga region, bearing the risk of double counting.

Conservation of Caatinga also occurs on farmland. The Forest Code prescribes that $20 \%$ of the farmland in the Caatinga biome must be conserved as a legal reserve, while sustainable use according to management plans can be granted. Farmland on riparian zones and hilltops must be set aside for full preservation (APP by its Brazilian acronym). The APP areas make up about 5\% of farmland (Riegelhaupt and Pareyn 2010). The CAR is meant to shed light on current conservation practices at the farm level. Depending on the style of farming, further areas of farmland can constitute important habitats for biodiversity conservation as well. Farm level conservation, along with a few official private conservation areas (RPPN by its Brazilian acronym), represents a major pillar of overall land conservation. On the landscape and regional level, these areas are, however, rather disconnected from each other as conceived individually at farm level, as well as disconnected from governmental conservation strategies.

\subsection{Commercial and subsistence uses}

Typical uses of standing Caatinga vegetation are in decreasing order of species richness (Lucena et al. 2007): as construction wood, fuelwood (charcoal and firewood), medicine, technological uses (i.e., tools, toys, objects, crafts), fruits, and fodder. The direct use of standing vegetation occurs as natural pastures for small and large ruminants and for beekeeping. Even small portions of water can be harvested from root tubers and branches of certain species-a survival technique of historical relevance. Many bird species are utilized and sold as pets, while (illegal) hunting is also relatively widespread, e.g., hunting of armadillo, anteater, and skunk (de Albuquerque et al. 2012).

Araújo Filho was the major pioneer and advocate for sustainable silvo-pastoral use of the Caatinga. He and his team undertook research at a regional branch of the Brazilian Company for Agricultural Research for many years and developed a system that is compatible with farmer needs, i.e., feeding livestock in a more intensive way than just using natural pasture, while sustaining the regional vegetation cover to a wide extent (Araújo Filho 2014). He proposed three features in particular: lowering of specific shrubs and trees, thinning of specific shrubs and trees, and enrichment with robust grass species. The techniques 
aim to increase the palatable biomass and its nutritional value. This results in changes to the initial biodiversity, although part of the vegetation remains in place.

Further scholars developed sustainable management practices of Caatinga logging (Riegelhaupt et al. 2010). These systems display less deviation from the natural vegetation cover as they focus on the sustainable harvesting of existing species. This system, however, needs substantial space per farmer as the returns are rather low per unit area. Special scope for sustainable forest management and harvesting of fuelwood is considered to be best realized by farms with more than 200 ha farm size (Pareyn 2010). This farm size is about four fiscal modules in the region (each 55 ha in Floresta) (INCRA 2013), coinciding with the threshold definition for family farming. In 2017, the average farm size in Floresta was just 57 ha (IBGE 2017). Nevertheless, management plans for small units within communal arrangements (federal or state settlement schemes) are also promoted to make a living from such a management system. Immediate sales of entire stands are, obviously, an easier and quicker way to earn money, although finite.

Preference for and promotion of non-wood tree products, along with environmental awareness-raising, is likewise endorsed as a promising pathway toward the conservation of native natural resources. Out of the three tree species that experienced the highest use-pressure in a study, two were species threatened by extinction (Lucena et al. 2007). The nonwood harvesting in native stands needs substantial space in order to make a living. Moreover, many factors impact the decision to plant for instance a native tree to raise income from fruit harvesting (Rodorff et al. 2018). The school of thought about non-wood tree product uses is not very different from the above-mentioned sustainable management of logging, since both seek a careful harvesting regime that is conserving the tree resources in the long term. In this respect, it is interesting to mention the construction of fences, which can both reduce biodiversity (dead posts) or promote it through living fences (Nascimento et al. 2009).

When conceptualizing Caatinga as space, we see that typical uses are slash-and-burn and slash-and-sell of the woody vegetation, potentially followed by land uses such as cropping, using wood for the construction industry, flooding to form a water reservoir, or simply abandoning it. Many rain-fed farms exist, which are partly backed by local irrigation facilities, such as small reservoirs. Large irrigation schemes are located near major reservoirs and the São Francisco River. Several schemes are the result of forced resettlement after reservoir formation. Additional irrigation schemes are planned by the regional development company CODEVASF, although water availability simulations suggest that clear deficits may occur in the drier months (Koch et al. 2015). Plantations of alternative trees, e.g., Eucalyptus spp., are suggested as a means to generate biomass for combustion, which may mitigate the substantial slashing of Caatinga for fuelwood, for instance for the gypsum industry (Gadelha et al. 2012; Silva 2008). Necessary preconditions are, however, closing the water and nutrient demand gap and a thorough analysis of its sustainability and socioeconomic implications. The short-rotation coppice cultures temporarily re-establish forest cover. They are generally monocultures, of clones in the case of Eucalyptus, and should, in opposition to current practice, not be subsumed in registries under forest or reforestation, but under crop production and should appear in the agricultural census data, since diversity is marginal and clear cuts necessarily occur within few years. The current boom of wind and solar power facilities' deployment in the semiarid region is further land-consuming, while the vegetation can partly be kept in place. In particular, it can complement shortcomings of water availability for hydropower generation under climate change, whereas the deployment process needs again careful consideration of its social and environmental implications (Koch et al. 2018). 
Large urban centers in the Caatinga region (Caruaru-PE, Campina Grande-PB, CratoBarbalho-CE, Petrolina-PE/Juazeiro-BA) are examples for vibrant modernization within the semiarid environment ("Appendix 1": social, economic, and political settings [S]). Although partly strongly related to agriculture, e.g., in the case of Petrolina-Juazeiro based on irrigated agriculture at commercial scale, these emerging centers thrive since they developed alternatives to livelihoods which fully rely on natural resource use. When people are depending less on the Caatinga vegetation for making a living, pressure on this natural resource base lowered and new options for approaching Caatinga emerge, such as enjoying nature and its related culture as a leisure or tourism activity. Nevertheless, the supply of freshwater remains a concrete dependence of the urban agglomeration on its natural environment, which makes the conservation of vegetation cover a must.

\subsection{The institutional environment}

The governance dilemma of the Caatinga region ("Appendix 1": focal action situation [I and O], governance systems [GS], and actors [A]) consists of a weak institutional setting due to low lobbying, little or no funds and fragmented groups. The institutions and organizations involved are hardly able to face the degradation threats (compare the following section on Caatinga dynamics). Local societal framings of Caatinga are as diverse as the stakeholders: a commodity (i.e., wood), space, specific ecological conditions to live with, or wilderness. Issues of international societal framing focus on carbon sequestration, biodiversity, and water retention. In terms of vegetation classification using satellite images,

Table 1 Selected regulations that address forest regions at federal (Brazil) and state level (Pernambuco)

\begin{tabular}{lll}
\hline Federal & State (PE) & Description \\
\hline $23793 / 1934$ & & Forest Decree (legal status for national parks) \\
$4771 / 1965$ & Forest Code (legal reserve-RL; permanent protection areas_APP) \\
$6938 / 1981$ & Environmental Law (National System of the Environment-SISNAMA) \\
1988 & Constitution (Art. 23: preserve forests, fauna and flora) \\
$8171 / 1991$ & Agricultural Policy (chap. VI: environmental and natural resources protection) \\
& $11206 / 1995$ & State Forest Code \\
$9433 / 1997$ & & Water Act (harmonizes management of water, land use, and environment) \\
$9478 / 1997$ & & Energy Act (payment of royalties for affected states and municipalities) \\
$9605 / 1998$ & & Environmental Crimes Act (penalties for cutting trees in RL and APP) \\
$9985 / 2000$ & & National System of Protected Areas-SNUC \\
$4297 / 2002$ & & Decree about ecological-economic zoning-ZEE \\
$11097 / 2005$ & & Emphasizes the use of alternative energy sources to the dominating petrol \\
$11284 / 2006$ & & Promoting sustainable production in federal forests \\
& $13787 / 2009$ & State System of Protected Areas-SEUC \\
$12187 / 2009$ & & National Policy on Climate Change-PNMC (reforest and protect forests) \\
& $14090 / 2010$ & Combat climate change \\
& $14091 / 2010$ & Fight against desertification \\
New Forest Code (rural environmental register-CAR) \\
$13465 / 2017$ & $14922 / 2013$ & $\begin{array}{l}\text { Dealing with the semiarid region } \\
\text { Regularization of land tenure }\end{array}$ \\
\hline
\end{tabular}


the low vegetation density of the Caatinga is easily mistaken with shrubland or even wasteland, which makes its quantification very difficult.

Regulations about Caatinga issues are firstly forest-related (Table 1). A decree from 1934 was a predecessor of the 1965 Forest Code and its updated version in 2012. Yet, regulations of the manifold related sectors are to be considered simultaneously: the environment, agriculture, water, climate change, desertification, tenure, and energy, among others. Table 1 also lists selected state regulations for Pernambuco as an example. Some are obviously the implementations of the federal acts, while the one about dealing with the semiarid region is a response to the regional context.

Brazil's major instrument for land planning from an environmental perspective is the ecological-economic zoning (ZEE), specified by a federal decree from 2002. Other sectoral zonings exist, such as urban, industrial, and those about climate risks for agriculture. Embrapa, the national council for agricultural research, concluded a characterization of the Caatinga area in 2008, where soils and agricultural opportunities were mapped in an agroecological zoning. A ZEE of the biome is, however, not yet available. In 2018, a ZEE of the São Francisco River Basin was completed. This watershed covers approximately $30 \%$ of the Caatinga biome. The ZEE is diagnostic and analyses future scenarios. It provides a general orientation, for instance, it suggests coming up with management plans for established protected areas (Nemus and MMA 2018).

The states had a (first) deadline of 2017 to perform their state ZEEs as set by the Forest Code from 2012. All states initiated their zoning tasks (MMA 2017). Some states break down their zoning into regional sub-zonings, providing some higher resolution within more homogenous regions. These studies are being complemented (or partly repeated) by a nationwide program to monitor the Brazilian biomes on an annual basis, which has been set up in 2015 by a group of NGOs, universities, and companies. Concrete efforts in restoration of riparian vegetation and areas around sources have been initiated by the committee of the São Francisco River Basin as a response to land use changes for water diversion at large scale (Machado 2008), which has been institutionalized later on. This committee has a budget due to the payments for water abstraction. Monitoring of the efforts' effectiveness is, however, rare.

Setting land aside for conservation by governments is a rather recent concept. The first Caatinga national forest was created in 1946, and the first Caatinga national park was created in 1959 (Rylands and Brandon 2005). Issuing the National System of Protected Areas (SNUC by its Brazilian acronym) in 2000 was fundamental in spurring the creation of protected areas. The creation of UNESCO conservation areas followed: a Caatinga Biosphere Reserve in 2001 and the Araripe Global Geopark in 2006. While in most areas the Caatinga biome has a flat to gently sloping relief and may appear unspectacular, its major highlights - such as its sudden blossoming after the onset of the rainy season, rock formations, caves (some of which are used for cultural-religious purposes), petrified tree trunks, animal and plant fossils, and prehistoric paintings - are still rarely appreciated or advertised to the non-native general public.

Some players at the global level have gained visibility in recent decades. The Brazilian decree no. 11701 from 21/7/2008 created the national committee to combat desertification, which got the mandate to collaborate with the United Nations Convention to Combat Desertification (UNCCD). Recently, UNCCD has put soil at the center of the degradation discourse through the land degradation neutrality (LDN) paradigm, linked to achieving the Sustainable Development Goals (in Particular No. 15.3) (Akhtar-Schuster et al. 2017; Kust et al. 2017). Brazil thus accepted implementing LDN. Article 102 of the Brazilian Agricultural Policy, institutionalized in 1991, already stated that soil shall be respected as a 
national patrimony. The parties of the Convention on Biological Diversity (CBD) adopted in 2010 the strategic plan 2011-2020, containing the worldwide Aichi Biodiversity Targets. Pacheco et al. (2018) strongly doubt that the Caatinga's protected areas will truly reach target 11: $17 \%$ protected. This is because most of the protected areas fall under the sustainable use paradigm, where human interference can still be high and can potentially threaten biodiversity.

\subsection{Dynamics in Caatinga}

The conceptual model of change and degradation occurring in Caatinga is focused on concrete activities on the ground as well as climate change impact (Fig. 3). Partial harvesting of vegetation, grazing, and cropping are diminishing photosynthesis of the native vegetation and may impact soil processes. Game hunting and bird catching threaten entire animal populations and their roles in the ecosystem. Clear cutting for purposes such as urbanization, mobility infrastructure and industry generally seals the soil surface and sharply reduces the previously existing ecosystem services. At the same time, these are also threatened by climate change. Extremes of temperature and water availability amplify the inherent climate variability of semiarid climate zones such as the Caatinga region. The outcome of anthropogenic and climatic interference can be called change or, with a negative connotation, degradation. The terminology employed frames the view on Caatinga processes.

There are several ways to reduce the numerous adverse effects of humans on Caatinga. The official creation of protected areas is just one way to counteract degradation. At least

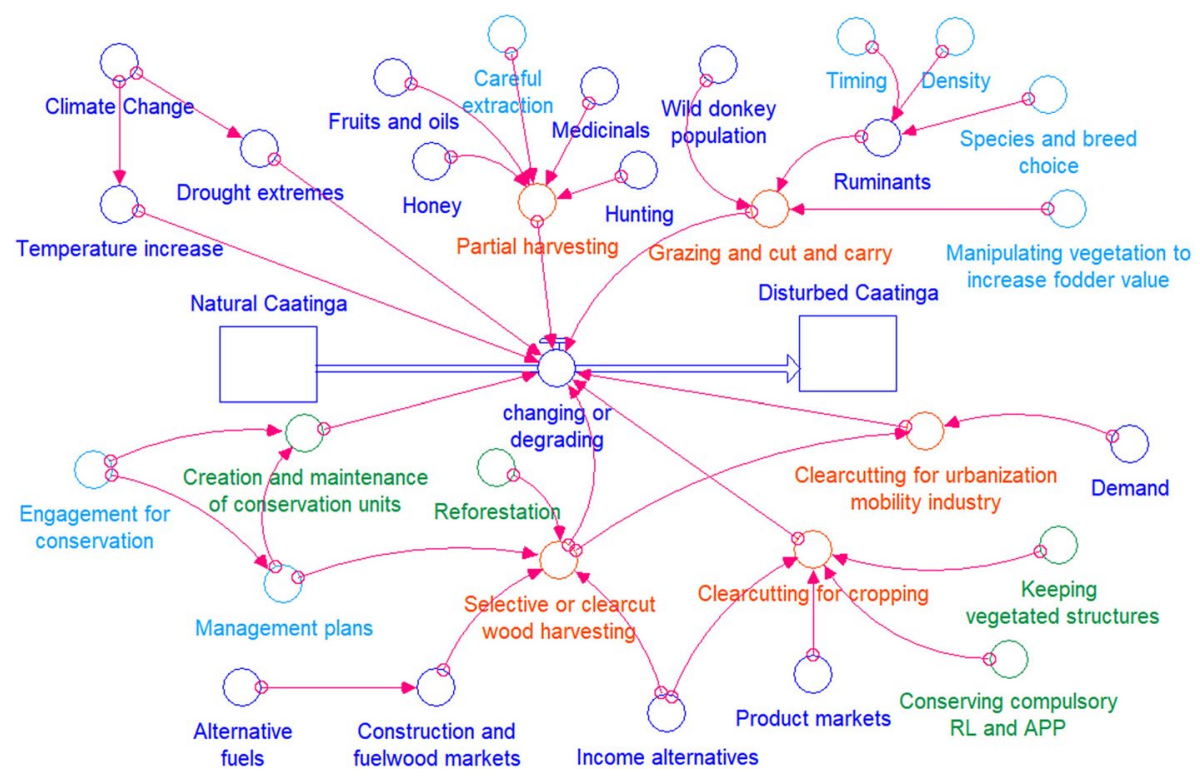

Fig. 3 A conceptual system dynamics model of change from undisturbed to disturbed Caatinga and levers to counteract it. Legend: Stocks are boxes and circles are converters. The major (commercial) anthropogenic activities are named in orange, while green highlights concrete forest maintenance and restoration attempts and light blue critical levers in anthropogenic interference. RL: legal reserve; APP: permanent preservation area 
partial preservation can be realized at farm level when conserving the compulsory reserves (legal reserves, and permanent preservation areas). At the plot scale, conservation could involve leaving vegetated structures in or around plots to safeguard habitats of natural enemies of crop predators (Cierjacks et al. 2017). Establishing and implementing management plans are important steps forward in a management that not only favors short-term returns to people, but also long-term benefits to nature and, ultimately, people, too. Officially protected areas require such plans, but these are often lacking or are not implemented. The lack of such management plans is especially widespread in the Caatinga, where only $8 \%$ of the protected areas have one (MMA 2019a). In comparison, the values for the Cerrado and the Amazon are $16 \%$ and $27 \%$, respectively.

Furthermore, beneficial interlinkages exist (not displayed in Fig. 3). For instance, keeping the compulsory conservation areas intact at farm level provides space and feed for wild animals as stepping stones, feeds bees and supports their pollination service. Conversely, there are negative externalities due to the disturbance of the Caatinga, such as carbon dioxide release, soil erosion, and rainwater runoff after clear-cutting, which adds to greenhouse gas emissions and reduces the availability of nutrients and water for subsequent cropping. And there is a decline of insects and amphibians, which can play an important role in pest control but are reduced due to habitat degradation.

\subsection{An initiative-based learning process at the municipality level}

The constellation analysis (Fig. 4) gives insight into efforts toward conserving a specific area, the Serra da Canoa, in the municipality of Floresta, Pernambuco (Figs. 1, 2). The 7.6 million ha are recognized at the state level as a so-called ecological station (Pernambuco 2012), which means full protection, only allowing research and environmental education activities (Pernambuco 2009). A local NGO was the driving force of the process, seeking the preservation of their own environment and making use of the state regulation about the creation of protected areas (SEUC). The State Environment and Sustainability Department (SEMAS) finally settled the creation process in cooperation with the State Environment Agency (CPRH). The State Committee for the Creation of the Caatinga Biosphere Reserve (CERBCAA/PE) contributed to it. After a series of studies about the state of the biodiversity, which led to the proposal for creating the protected area (CPRH and SEMAS 2012), a public hearing, commissioned by SEMAS, was part of the process, where the local residents were consulted. Nevertheless, this hearing took place only a few days before the approval by the State Council of the Environment (CONSEMA/PE) and the signing of the official document by the State Governor in April 2012. The regional development company CODEVASF had environmental liabilities, such as from establishing irrigation schemes on former Caatinga areas. To compensate for the liabilities, they purchased the designated land from local owners to create the ecological station.

The station is neighboring a local set of small conservation areas at the farm level. As mentioned above, farmers in the Caatinga region have to conserve $20 \%$ of their farm area (legal reserve) and permanently preserve the vegetation along water bodies and on hilltops (APP) (Brazil 2012). Farmers currently comply with these requirements to very different extents. The short-term benefits from slashing vegetation count more than conservation for some people, including other residents. For livestock keepers, conserving the vegetation to a certain extent makes sense to secure feed resources for their animals. Very committed landowners do even more to conserve and create official reserve areas, which are still private (the already mentioned RPPN). The latter can be used in a sustainable way, according 


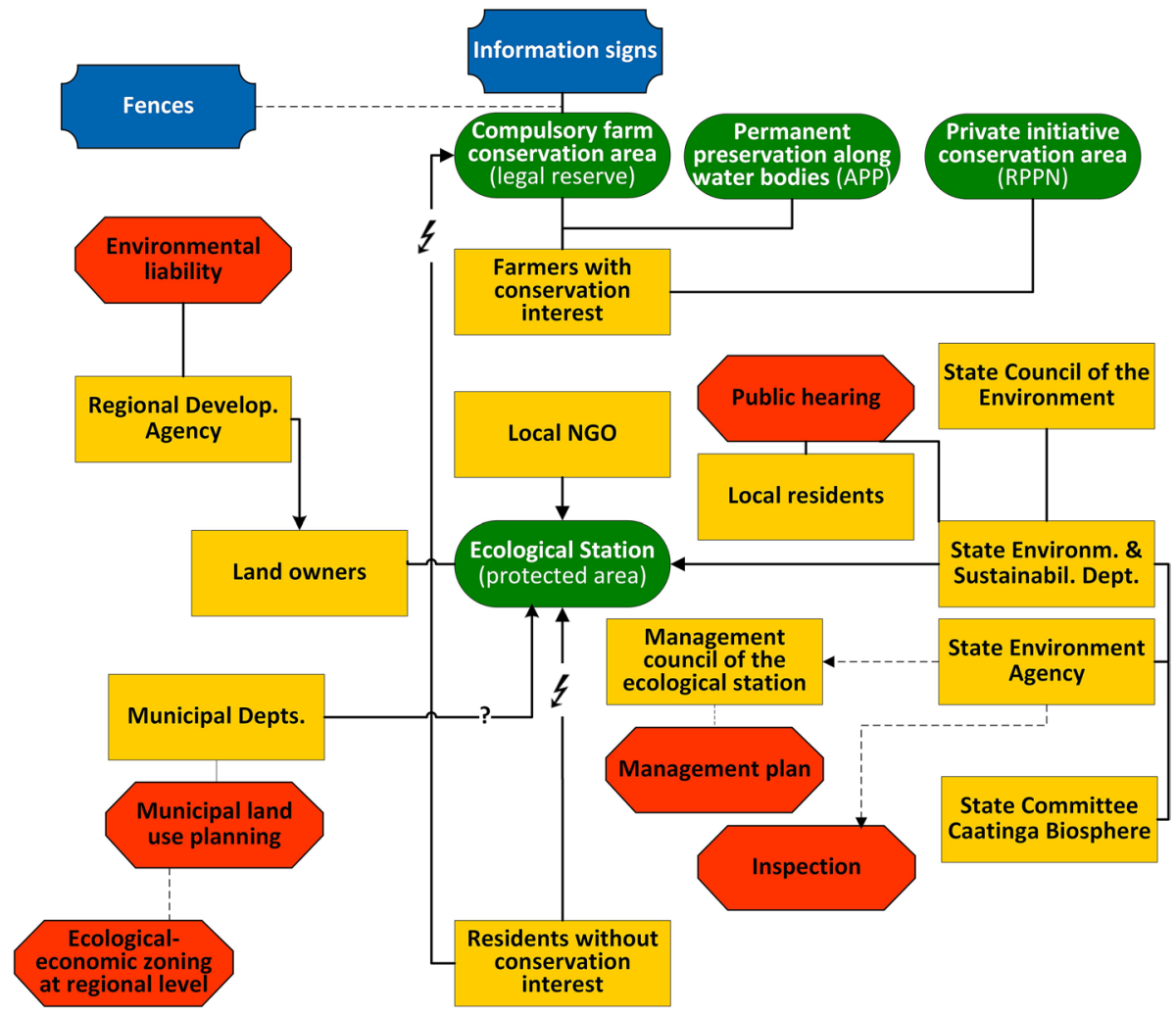

Fig. 4 The constellation of efforts toward the conservation of Caatinga at the ground: the case of the ecological station Serra da Canoa in Floresta municipality. Legend: Yellow-actor; Red-regulation, concept; Green-natural component; Blue_technical object; Line with arrow-directed relationship; Dotted linemissing relationship (respectively missing element); Lightning sign-conflict; Question mark-unclear relationship

to a respective management plan. Their numbers and sizes are, however, rather small-one in Floresta conserves 285 ha. Further protected areas at the municipal level are a federal Biological Reserve of 2039 ha, where land of traditional communities is partly overlapping and adjacent to this reserve, which is not part of official conservation efforts but is possibly rather well conserved.

The general public was in favor of creating the ecological station. Nevertheless, this benevolence was not reflected later in the implementation of the protected area. Settlements emerge in conservation areas, while inspection and sanctioning are almost absent. Generally, areas are simply declared by information signs, a more obvious indication by fencing the area is missing. Efforts by the respective municipal departments to integrate the protected areas into its municipal land use planning and to steer the transition from using to conserving the newly delimitated area and its surroundings are so far rare. CPRH, the authority responsible for implementing and steering the protected area, is not actively involved in the next steps: establishing a management council and writing a management plan for the ecological station. Hence, the new protected area is still part of the first generation (just on paper), while a management plan and the creation of a management council 
would qualify for "second generation" (SEMAS 2012). A third-generation protected area would mean developing supportive and integrative activities, such as green economy initiatives which benefit the neighboring residents. Such activities are incipient, though not very pronounced thus far. The attitude of the municipal government, i.e.,its relationship with the protected area in the constellation, remains unclear. Moreover, planning at the federal level is incomplete. The ecological-economic zoning of Brazil's Northeast region, as well as at the state level, is missing. The zoning of the São Francisco River Basin, which includes Floresta, was completed recently. Nevertheless, these studies have limited relevance for planning at the ground level.

\section{Lessons learned from the case study}

\subsection{Strategic coordination is missing}

A strategic coordination among the depicted players in the governance of the Caatinga region is not recognizable to date. There are emerging activities that are making a case for the Caatinga, involving local activists, selected authorities and the specific scientific community. The initiatives cover a wide range from sustainable use to strict protection. The data gaps presented, the limited financial resources and conflicting demands, and assessments of relevance are obstacles to reaching a consensus on sustainable transformation. The actions occur even under difficult conditions, but cooperation is limited, and activities remain fragmented. The environmental adaptation peculiarities—rich biodiversity, beauty, history, human achievements, and uniqueness of the region-are reasons for advocating for it but their value remains contested thus far.

Much remains to be done to change the region's negative reputation. Serious efforts are needed to counteract the long-standing prejudices against the autochthonous population, which led to a generally negative connotation with the region. This would involve advancing place-based environmental education aimed at developing a positive view of society about the semiarid region and the Caatinga biome in particular (Souza et al. 2014). First indications for an increasing awareness of the Caatinga region by the Brazilian population are to be registered. Among the top 10 national nature reserves visited in 2018, one Caatinga area ranked 6th (MMA 2019b). The effects on the renewal of the view of the region at national to international level remain to be seen.

\subsection{Campaigning for sustainable use and conservation}

The local NGO in the Floresta municipality was fundamental in initiating the process that led to the institutionalization of the Serra da Canoa protected area. The presence of organized civil society is a clear advantage in implementing the policy for protected areas, which carries the premise of public participation. A broader public and governmental participation appears, however, to be necessary to functionally implement and maintain the protected area in the medium to long term. The proposal for the creation of the protected area was rather rough, probably because it was an early one in a series of such studies. A slightly more recent study (SEMAS and UNIVASF 2014) is much more detailed, in particular in regard to the affected social system. It considers, among others, the history of the region and the current actor groups of the civil society. 
The local NGO interacted with the state committee for the Caatinga biosphere to bring the conservation issue onto the state agenda. They also aim to reach out to the federal level to increase odds for effective conservation through capturing more funds and visibility. The coordination and reconciliation of competing uses and protection is a very local issue, which cannot be solved by state or federal level organizations alone. Cooperation across administrative levels and inclusion of several local actor groups is crucial. One common drawback is the lack of cooperation between actors who focus on technical approaches with actors who consider cultural values and beliefs (Faggin et al. 2017). The latter is often essential in joint decision-making processes.

Mainstreaming biodiversity conservation into diverse sectors can take place through framing, taking advantage of willing coalitions, valuation, and strengthening business cases with biodiversity (PBL 2014). This is only marginally recognizable in the study region so far. While protecting areas diminishes agricultural options within these areas, they can provide alternative opportunities to knowledgeable people, promote environment-friendly practices in the surroundings, and be central to environmental education. Thinking within the dichotomy of "development vs conservation" is merely a sign of ignorance (Klink and Machado 2005). Agriculture, for instance, has not to be oppositional to conservation: In particular, agroecology can bridge the divide between use and conservation by promoting sustainable use (Shiki 2010), multiplying the experience of many family farmers (Petersen and Silveira 2017). Yet, associated power relations need close observation since they can be a root cause of ineffectiveness (Brannstrom et al. 2012).

The constellation (Fig. 4) displays actors, regulations/concepts, and natural components, but few technical objects. This is because the main infrastructure in our case consists only of information signs that roughly identify a conservation area, e.g., a legal reserve of a public irrigation system. Fences could be useful to provide clearer guidance about the existence and location of conservation areas and to lock out free-roaming livestock. In addition, living fences themselves could further contribute to nature conservation when native plant species are employed (Nascimento et al. 2009). Nevertheless, fencing and maintaining fences are quite laborious given the vast extent of the areas.

\subsection{Conservation and use must happen in an integrated manner}

The laws about nature conservation are comprehensive and anticipate integration among sectors, similar to the Water Act (Siegmund-Schultze et al. 2015). The Forest Code (Brazil 2012) establishes that the localization of the legal reserve at the farm level shall consider (i) the management plan of the particular river basin, (ii) the ecological-economic zoning at state level, (iii) the forming of ecological corridors together with other legal reserves, APPs, protected areas and further legally conserved areas, (iv) areas with major importance for biodiversity conservation, and (v) areas of major environmental vulnerability. This is certainly a very demanding task, which is almost impossible to fulfill for many smallholders. At a substantial farm size, the integration of different types of information might be possible, although there are no reports to our knowledge that farmers indeed did so. Incentives and support by government or non-governmental actors with good insight appear to be crucial. Part of the aforementioned plans is not very detailed at the municipality level (as far as the ZEE of the São Francisco River Basin is concerned), or does not yet exist (e.g., at the Pajeú River, a tributary to the São Francisco River). A first step toward a local river basin management plan is made through the creation of tributary basin 
committees. The lack of such organizations is, however, a common phenomenon in the region (Souza Júnior et al. 2017).

The task of the river basin committees, the state committees of the Caatinga biosphere, the State Council of the Environment (see Fig. 4), and other pertinent committees and councils are to promote integration among governmental and non-governmental actor groups of diverse sectors at different administrative levels. The ambitious idea is sustained by its members representing such groups (to different degrees), while most committees and councils enjoy only a deliberative mandate. The success of this institutionalized cooperation is unclear, given the many uncoordinated policies and planning procedures. One could hypothesize that the institutionalized cooperation is just pro forma and works on the spot, while the commitment stops when the members leave their inter-sectoral meetings. A new way of thinking is needed, which mainstreams inter-sectoral assessment and incorporates conclusions into planning. However, scholars argue that reconciliation between conservation and commercial production (e.g., agriculture) cannot succeed as long as the underlying value systems of the competing advocators are not made explicit and put into question, i.e., the capitalist premise of the state counteracts any comprehensive conservationist efforts (Frota and Frota 2018).

The concept of multi-level governance highlights the existence and relevance of organizations at different levels, such as municipal, state and federal in Brazil. Realities and visions at these levels certainly differ, since different tasks are at stake. Commonly, the "highest" level issues regulations, e.g., a federal act that is implemented at "lower" levels, hence adopting and adapting state regulations, while practical implementation usually takes place at the municipal level. Yet, the clear order of government levels is not the only regulatory force. Spatially overlapping responsibilities have been likewise suggested and partly implemented. Polycentric governance builds on an array of level independent and potentially flexible steering organizations or coalitions (Nagendra and Ostrom 2012). River basin committees and regional development associations are examples for institutions and organizations that transcend the administrative hierarchical levels of the governmental system (see SiegmundSchultze (2017), pp. 24-25, Table 3). Private land owners can choose between applying for a state or a federal recognition of their designated RPPN protected area. The RPPN also stands out since they are officially recognized but enjoy private management. In our example, the area to be conserved was indicated by local civil society, but implementation and management remain primarily a government responsibility, while concrete action occurs again at the local level. This interdependence therefore requires integration and focused cooperation.

\subsection{Framings of conservation and use}

Using the terms change or degradation of land and biodiversity triggers different associations. While a clearly negative tone resonates with degradation, this is less clear with change. Humans are both "actively maintaining and promoting the local phenotypic diversity" (Lins Neto et al. 2012). The biodiversity of a certain place is not fixed, but rather, it undergoes continuous changes due to local anthropogenic and wildlife uses and global influences, such as climate change. The question is rather the extent of change that is accepted and whether the change involves the reduction, absence, or extinction of species, or the degree of invaders dominating the system. From an individual or disciplinary viewpoint, the same change can be seen as good or as bad as has been observed for changes of the riparian vegetation along the Brazilian São Francisco River (Silva et al. 2014). Stakeholder rarely discloses their values and value systems for the Caatinga in the public discourse. 
Mirrored also by our examples, the forest policy discourse in Brazil is, generally speaking, framed as three different pathways: socioenvironmentalism, agribusiness, and "green capitalism" which means tree plantation companies (Kröger 2017). In particular, the agribusiness sector has taken advantage of the government's weak enforcement of environmental laws (Soares-Filho et al. 2014). The adopted environmental reserve quota system along with payments for ecosystem services can be fundamental in reducing deforestation and in securing environmental benefits (Soares-Filho et al. 2014). These mechanisms use the appropriate "language", namely economic arguments, to address agribusiness and tree plantation companies. However, the mechanisms do not necessarily match the needs and values of the "broad social movement that does not see nature as an obstacle" (Kröger 2017). And it is important to recognize the policy dynamics at the ground level when formulating global policies (Faggin and Behagel 2017); likewise, people on the ground do not always take decisions at the global level into account or are sufficiently aware of them. Hence, an approach that is inter-sectoral and addresses all pathways and levels is necessary to advance toward a coherent balance between use and conservation.

To such an end, our conceptual model (Fig. 3) can be transformed into a mathematical model, using indicators. The three suggested indicators of land degradation neutralitysoil organic carbon stocks, net primary productivity, and land cover (UNCCD 2016) could for instance serve as a model currency. Likewise, biodiversity fluxes could serve as currency, for instance using species diversity to explore effects of grazing intensity-where timing, animal density, choice of species and breeds, and manipulation of the natural range are pertinent anthropogenic levers, as suggested by our conceptual model.

In addition to the UNCCD, the Convention on Biological Diversity (CBD) and the United Nations Framework Convention on Climate Change (UNFCCC) similarly deal with natural resource use. Particularly the ecosystem approach of the CBD emphasizes the connectedness of physical and social systems, bridging between issues of use, conservation, and fair benefit sharing, while UNFCCC raises awareness for climate change and its implications. Brazil ratified the Conventions and endorses the implementation of the Sustainable Development Goals, which highlight necessary adjustments in very different but interrelated and indivisible fields. It is evident that a coordinated approach makes sense. Collaboration among a range of actors, including civil society, is essential for facing this challenge, ultimately strengthening the Caatinga case. However, sustainable institutional interventions at the landscape level are tricky and need careful preparation (Fischer 2018). The consideration of diverse perceptions, arising from multiple worldviews, together with the exchange of knowledge, seems to be a good path to cross-sector understanding and environmental mainstreaming (Okpara et al. 2018).

Analyzing governance arenas and their specific narratives is a first step in understanding diversity and framings (Köppel and Siegmund-Schultze 2019). Further steps are necessary to promote enabling environments for both conservation and environmentally friendly production under fair conditions. Accounting for the three proposed indicators of land degradation neutrality can provide guidance: managing carbon stocks, minimizing deforestation, and securing land productivity; plus key indicators about biodiversity, and socioeconomic indicators regarding farmers' livelihoods, power constellations, fairness, and conflict resolution. These indicators must also be examined and monitored for their interlinkages.

Finally, having several organizations and individuals in the Caatinga actor landscape is not the problem, but it is the way they interact or not. More interactions and exchange among the diverse actors are required and learning from each other. This paves the way to better align interests and tasks, which is thought to enhance overall societal benefits. A stance to thinking and decision-making is needed, which embraces the challenges of 
complex systems (Rogers et al. 2013). Actors at multiple levels can ultimately benefit from polycentric coalitions across sectors but need to learn how to do this.

\subsection{Methodological reflection}

The mix of methods used in this study supports a multifaceted explorative approach. It can similarly be useful in other cases where a basic consideration is missing or fragmentary. The social-ecological systems framework provides a systematic approach to describing complex human and environment networks. It is subjective: The user decides what to highlight and what to leave out. A reflective process is needed, where the concept of saturation is commonly used to explain the end of the process. However, the description is static and should therefore be combined with methods that focus on the interrelationships and feedbacks, on scales and dynamics. Constellation analysis and system dynamics are possible methods to this end. Constellation analysis scrutinizes configurations and reveals the relationships or missing connections between their components. System dynamics goes one step further by qualifying and/or quantifying flows and feedbacks. A flexible combination of such methods is useful, especially when data is scarce, and samples are small.

\section{Conclusions}

The governance arena of the dry forest is as fragmented as its protected areas. Nominal protection is increasing, while implementation and concrete impacts are rarely monitored. One motor for improvement seems to be the renewal of the societal reputation of the dry forest. Prejudices do not only hamper the agents' efforts, but also block the empathy and interest of outsiders. Local activists are at the forefront of effective governance and deserve an enabling environment. The pooling of forces can increase overall visibility and recognition of the largely neglected biome. The focus should be on building on existing structures and potential funding opportunities, such as river basin committees. Advocating the Caatinga dry forest should involve a clear demonstration of the multiple values of standing Caatinga vegetation, e.g., for water conservation and biological pest control.

Conservation and sustainable use efforts should be consistently integrated with relevant policies and programs and utilize the momentum of ongoing societal endeavors. The focus must be on interacting with and involving people, e.g., students, companies, government officials and citizens, on the diverse values of Caatinga, how Caatinga is threatened and what they can contribute. Listening is as important as tailoring information to people's specific interests and needs. Identifying inter-sectoral interactions, such as vegetation and water resources or biodiversity and biological pest control, is a prerequisite for inter-sectoral cooperation. Cooperation between governmental departments, private entities, and civil society shall be enhanced to improve the coherence of policies and programs through addressing conflicts and synergies.

Acknowledgements The research that was foundational for this article was supported by the German Federal Ministry of Education and Research (BMBF) under grant number 01LL0904A (INNOVATE project). Cooperation in the field and discussions about Caatinga issues with co-researchers of the project is gratefully acknowledged: in particular, Jarcilene Almeida-Cortez, Maike Guschal, Déborah Oliveira, Arne Cierjacks, Verena Rodorff, Sarah Gottwald, Guilherme Araújo, Edvânia Gomes, Marília Lyra, Aleixo Silva, Renata Carvalho, Johann Köppel, and Maria do Carmo Sobral. Many thanks go to the cooperating stakeholders for their dedicated exchange on Caatinga governance, and to the anonymous reviewers for their constructive comments. This work contributes to the Future Earth research agenda. 
Open Access This article is licensed under a Creative Commons Attribution 4.0 International License, which permits use, sharing, adaptation, distribution and reproduction in any medium or format, as long as you give appropriate credit to the original author(s) and the source, provide a link to the Creative Commons licence, and indicate if changes were made. The images or other third party material in this article are included in the article's Creative Commons licence, unless indicated otherwise in a credit line to the material. If material is not included in the article's Creative Commons licence and your intended use is not permitted by statutory regulation or exceeds the permitted use, you will need to obtain permission directly from the copyright holder. To view a copy of this licence, visit http://creativecommons.org/licenses/by/4.0/.

\section{Appendix 1}

Diagrammatic presentation of the social-ecological system (SES framework) of Caatinga, focused on vegetation cover loss.

Social, economic, and political settings (S)

S1 - slow, in some regions accelerating economic growth; S2 - overall increasing population; S3 - elections able to freeze activity and change personnel; S5 - market mainly in commercial cluster areas; S6 - little media coverage; SP7 - high tech to basic technology in use

Resource Units (RU)

(a) Soil:

RU1 - threat of erosion

RU2 - slow formation

RU6 - shallow and stony, or sand

RU7 - spatial differences of soil types,

depth, fertility, stability

(b) Flora:

RU2 - slow growth

RU3 - determined by soil water and

nutrient content and holding capacity

RU4 - commercial value and timber, fuel,

fruits, medicine, feed, shadow, fences

RU6 - many endemic, some invasive

exotic species

RU7 - spatial community differences

(c) Fauna:

RU1 - differently mobile fauna

RU6 - can provide pest control in crops,

pollination, plant seed dispersion

(d) Livestock:

RU1 - hard to control mobility (goats)

RU4 - use and commercial value

RU6 - weight reduction during droughts

Resource Systems (RS)
RS1 - diverse agricultural
and non-agricultural uses
RS2,3 - recurrent redefinition
of boundaries and size
RS5 - low productivity,
renewable, vulnerable
RS8 - carbon storage in soil
and flora, intact habitats
preserve water resources

Focal Action Situation: Loss of vegetation cover Interactions (I) $\rightarrow$ Outcomes (O)

I1 - partial harvesting vs slash-and-burn

14 - use vs conservation; competing user groups

16 - Caatinga advocators not much heard

17 - active NGO with locally restricted influence

19 - little monitoring and sanctioning takes place

O1 - productivity: short-term increases possible, long-

term decrease; heritage loss

$\mathrm{O} 2$ - changes in biodiversity, overhunted/overgrazed

$\mathrm{O} 3$ - migration of people
Governance Systems (GS)

( Federal: MMA, ICMBio, IBAMA, SFB, MAPA, MI, ANA, CEVASF, MME; State-PE: CPRH, SEMAS, SECTMA,

CONSEMA, IPA; municipal government departments GS3 - networking difficult due to fragmented governance system GS4 - private and state land, partly commmunity-managed GS5 - smallholders seek to secure livelihoods, commercial farming is connected to world market

GS6 - partly imposed collective management of legal reserves GS8 - prescribed monitoring of conservation areas widely absent

Related Ecosystem (ECO) ECO1 - Semi-arid, high inter-annual precipitation variability, recurrent and prolonged droughts

The variable labels follow the updated list of McGinnis and Ostrom (2014). Abbreviations of organizations: MMA Ministry of the Environment; ICMBio Chico Mendes Institute for Biodiversity Conservation; IBAMA Brazilian Institute of Environment and Renewable Natural Resources; SFB Brazilian Forestry Service; MAPA Ministry of Agriculture, Livestock and Food Supply; MI Ministry of National Integration; ANA Federal Water Agency; CODEVASF Development Company for the São Francisco and Parnaíba Valleys; $M M E$ Ministry of Mines and Energy; CPRH State Agency for the Environment; SEMAS State Department of the Environment and Sustainability; SECTMA State Department of Science, Technology and the Environment; CONSEMA State Council for the Environment, IPA Agricultural Institute of Pernambuco, SOS Caatinga local NGO, CERBCAA/PE Council for the Caatinga Biosphere Reserve, Pernambuco; $C B H S F$ Committee of the São Francisco River Basin 


\section{References}

Akhtar-Schuster, M., Stringer, L. C., Erlewein, A., Metternicht, G., Minelli, S., Safriel, U., et al. (2017). Unpacking the concept of land degradation neutrality and addressing its operation through the Rio Conventions. Journal of Environmental Management, 195, 4-15.

Alarcon, G. G., Ayanu, Y., Fantini, A. C., Farley, J., Schmitt Filho, A., \& Koellner, T. (2015). Weakening the Brazilian legislation for forest conservation has severe impacts for ecosystem services in the Atlantic Southern Forest. Land Use Policy, 47, 1-11.

Albuquerque Júnior, D. M. (2004). Weaving tradition: The invention of the Brazilian Northeast. Latin American Perspectives, 31(2), 42-61.

Araújo Filho, J. A. (2014). Proposta para a Implementação do Manejo Pastoril Sustentável da Caatinga: MMA - Ministério do Meio Ambiente.

Barnett, A. J., \& Eakin, H. C. (2015). "We and us, not I and me": Justice, social capital, and household vulnerability in a Nova Scotia fishery. Applied Geography, 59, 107-116.

Barreto, C. G., \& Drummond, J. A. L. (2017). Strategic planning in Brazilian protected areas: Uses and adjustments. Journal of Environmental Management, 200, 79-87.

Basurto, X., Gelcich, S., \& Ostrom, E. (2013). The social-ecological system framework as a knowledge classificatory system for benthic small-scale fisheries. Global Environmental Change, 23(6), 1366-1380.

Beuchle, R., Grecchi, R. C., Shimabukuro, Y. E., Seliger, R., Eva, H. D., Sano, E., et al. (2015). Land cover changes in the Brazilian Cerrado and Caatinga biomes from 1990 to 2010 based on a systematic remote sensing sampling approach. Applied Geography, 58, 116-127.

Brannstrom, C., Rausch, L., Brown, J. C., de Andrade, R. M. T., \& Miccolis, A. (2012). Compliance and market exclusion in Brazilian agriculture: Analysis and implications for "soft" governance. Land Use Policy, 29(2), 357-366.

Brazil. (1988). Constituição da República Federativa do Brasil de 1988: The Brazilian Constitution.

Brazil. (2012). Lei no 12.651, de 25 de maio de 2012: Act about nature protection (Forest Code).

Cierjacks, A., Almeida-Cortez, J. S., Schulz, K., Oliveira, D. A. S., \& Guschal, M. (2017). Technologies for an environmentally and economically sound irrigated agriculture. In M. Siegmund-Schultze (Ed.), Guidance manual: A compilation of actor-relevant content extracted from scientific results of the INNOVATE project (pp. 53-55). Berlin: Universitätsverlag der TU Berlin.

CPRH, \& SEMAS. (2012). Proposta para criação de Unidade de Conservação na Serra da Canoa, Município de Floresta/PE. https://de.slideshare.net/verasouto/proposta-esec-serradacanoa. Accessed 4 April 2018.

Albuquerque, U. P., Araújo, E. L., El-Deir, A. C. A., Lima, A. L. A., Souto, A., Bezerra, B. M., et al. (2012). Caatinga revisited: ecology and conservation of an important seasonal dry forest. Scientific World Journal, 2012, 205182.

Albuquerque, U. P., Soldati, G. T., Sieber, S. S., Ramos, M. A., de Sá, J. C., \& de Souza, L. C. (2011). The use of plants in the medical system of the Fulni-ô people (NE Brazil): A perspective on age and gender. Journal of Ethnopharmacology, 133(2), 866-873.

Faggin, J. M., \& Behagel, J. H. (2017). Translating Sustainable Forest Management from the global to the domestic sphere: The case of Brazil. Forest Policy and Economics, 85, 22-31.

Faggin, J. M., Behagel, J. H., \& Arts, B. (2017). Sustainable forest management and social-ecological systems: An institutional analysis of Caatinga, Brazil. Forests, 8(11), 454.

Falk, T., Spangenberg, J. H., Siegmund-Schultze, M., Kobbe, S., Feike, T., Kuebler, D., et al. (2018). Identifying governance challenges in ecosystem services management: Conceptual considerations and comparison of global forest cases. Ecosystem Services, 32, 193-203.

Fischer, A. P. (2018). Forest landscapes as social-ecological systems and implications for management. Landscape and Urban Planning, 177, 138-147.

Frota, A., \& Frota, M. (2018). Brazilian conservation under the light of historical materialism. Ecological Economics, 145, 472-475.

Gadelha, F. H. L., Silva, J. A. A., Ferreira, R. L. C., Melo, I. V., Jorge, D. L., Tavares, J. A., et al. (2012). Rendimento volumétrico e energético de clones de híbridos de Eucalyptus sp. no pólo gesseiro do Araripe, PE. Ciência Florestal, Santa Maria, 22(2), 331-341.

Givens, J. E., Padowski, J., Guzman, C. D., Malek, K., Witinok-Huber, R., et al. (2018). Incorporating social system dynamics in the Columbia River Basin: Food-energy-water resilience and sustainability modeling in the Yakima River Basin. Frontiers in Environmental Sciences, 6, 104.

Grau, H. R., Torres, R., Gasparri, N. I., Blendinger, P. G., Marinaro, S., \& Macchi, L. (2015). Natural grasslands in the Chaco: A neglected ecosystem under threat by agricultural expansion and forest-oriented conservation policies. Journal of Arid Environments, 123, 40-46. 
Grecchi, R. C., Gwyn, Q. H. J., Bénié, G. B., Formaggio, A. R., \& Fahl, F. C. (2014). Land use and land cover changes in the Brazilian Cerrado: A multidisciplinary approach to assess the impacts of agricultural expansion. Applied Geography, 55, 300-312.

IBGE. (2004). Mapa de Biomas do Brasil, primeira aproximação. Rio de Janeiro: IBGE.

IBGE. (2017). Censo Agropecuário 2017, resultados preliminares. https://sidra.ibge.gov.br/tabela/6635. Accessed 14 March 2019.

IBGE. (2018). Panorama Brasil. https://cidades.ibge.gov.br/brasil/panorama. Accessed 17 Feb 2019.

IBGE. (2019). População e ambiente. Volume de população e de domicílios (2010) para recortes físicoambientais. http://mapasinterativos.ibge.gov.br/recortes/index.html. Accessed 3 March 2019.

INCRA. (2013). Sistema Nacional de Cadastro Rural: Índices básicos de 2013. http://www.incra.gov. $\mathrm{br} / \mathrm{sites} / \mathrm{default} /$ files/uploads/estrutura-fundiaria/regularizacao-fundiaria/indices-cadastrais/indic es_basicos_2013_por_municipio.pdf. Accessed 4 May 2018.

Klink, C. A., \& Machado, R. B. (2005). A conservação do Cerrado brasileiro. Megadiversidade, 1(1), $147-155$.

Koch, H., Biewald, A., Liersch, S., Azevedo, J. R. G., Silva, G. N. S., Kölling, K., et al. (2015). Scenarios of climate and land-use change, water demand and water availability for the São Francisco River Basin. Revista Brasileira de Ciências Ambientais (Online), 36, 96-114.

Koch, H., Silva, A. L. C., Azevedo, J. R. G., Souza, W. M., Köppel, J., Souza Junior, C. B., et al. (2018). Integrated hydro- and wind power generation: a game changer towards environmental flow in the Sub-middle and Lower São Francisco River Basin? Regional Environmental Change, 7, 1927-1942.

Köppel, J., \& Siegmund-Schultze, M. (2019). As diversas arenas da governança das bacias hidrográficas. In A. Philippi Jr. \& M. C. Sobral (Eds.), Gestão de bacias hidrográficas and sustentabilidade. Manole: São Paulo.

Kröger, M. (2017). Inter-sectoral determinants of forest policy: The power of deforesting actors in post2012 Brazil. Forest Policy and Economics, 77, 24-32.

Kust, G., Andreeva, O., \& Cowie, A. (2017). Land degradation neutrality: Concept development, practical applications and assessment. Journal of Environmental Management, 195, 16-24.

Leal, I. R., Silva, J. M. C., Tabarelli, M., \& Lacher Jr., T. E., (2005). Changing the course of biodiversity conservation in the Caatinga of Northeastern Brazil. Conservation Biology, 19(3), 701-706.

Lima, J. L. S. (1996). Plantas Forrageiras das Caatingas: Uso e Potencialidades. Petrolina-PE: EMBRAPA-PNE/RBG-Kew.

Lins, E. N., Peroni, N., Maranhão, C. M. C., Maciel, M. I. S., \& Albuquerque, U. P. D. (2012). Analysis of umbu (Spondias tuberosa Arruda (Anacardiaceae)) in different landscape management regimes: a process of incipient domestication? Environmental Monitoring and Assessment, 184(7), 4489-4499.

Lucena, R. F. P., Albuquerque, U. P. D., Monteiro, J. M., Cecília De Fátima, C. B. R., Florentino, A. T. N., \& Ferraz, J. S. F. (2007). Useful plants of the semi-arid northeastern region of Brazil: A look at their conservation and sustainable use. Environmental Monitoring and Assessment, 125(1-3), 281-290.

Machado, A. T. D. M. (2008). A construção de um programa de revitalização na bacia do Rio São Francisco. Estudos Avançados, 22(63), 195-210.

Maciel, B. A. (2010). Unidades de conservação no bioma Caatinga. In M. A. Gariglio, E. V. S. B. Sampaio, L. A. Cestaro, \& P. Y. Kageyama (Eds.), Uso Sustentável e Conservação dos Recursos Florestais da Caatinga (pp. 76-81). Brasília-DF: Serviço Florestal Brasileiro.

Maciel, J. R., Ferreira, J. V. A., \& de Siqueira Filho, J. A. (2012). Modelagem de distribuição de espécies arbóreas na recuperação de áreas degradadas da Caatinga. In J. A. Siqueira Filho (Ed.), Flora das Caatingas do Rio São Francisco: História Natural e Conservação (pp. 231-263). Rio de Janeiro-RJ: Andrea Jakobsson Estúdio.

Mahlkow, N., \& Donner, J. (2017). From planning to implementation? The role of climate change adaptation plans to tackle heat stress: A case study of Berlin, Germany. Journal of Planning Education and Research, 37(4), 385-396.

McGinnis, M. D., \& Ostrom, E. (2014). Social-ecological system framework: Initial changes and continuing challenges. Ecology and Society, 19(2), 30.

MMA. (2017). Situação do ZEE no Brasil. http://www.mma.gov.br/gestao-territorial/zoneamento-terri torial/zee-nos-estados. Accessed 17 April 2018.

MMA. (2018). Unidades de Conservação por Bioma. http://www.mma.gov.br/images/arquivo/80229/ CNUC_JUL18-C_Bio.pdf. Accessed 01 March 2019.

MMA (2019a). Painel Unidades de Conservação Brasileiras. http://www.mma.gov.br/areas-protegidas/ cadastro-nacional-de-ucs.html. Accessed 07 March 2019.

MMA. (2019b). Parques nacionais batem novo recorde de visitação. http://mma.gov.br/component/k2/ item/15401-parques-nacionais-batem-novo-recorde-de-visitação.html. Accessed 20 Feb 2019. 
Nabavi, E., Daniell, K. A., \& Najafi, H. (2017). Boundary matters: the potential of system dynamics to support sustainability? Journal of Cleaner Production, 140, 312-323.

Nagendra, H., \& Ostrom, E. (2012). Polycentric governance of multifunctional forested landscapes. International Journal of the Commons, 6(2), 104.

Nascimento, V. T., Sousa, L. G., Alves, A. G. C., Araújo, E. L., \& Albuquerque, U. P. D. (2009). Rural fences in agricultural landscapes and their conservation role in an area of caatinga (dryland vegetation) in Northeast Brazil. Environment, Development and Sustainability, 11(5), 1005-1029.

Nemus, \& MMA. (2018). Elaboração do prognóstico e dos subsídios à implementação do macrozoneamento ecológico-econômico da bacia hidrográfica do Rio São Francisco. Relatório de plano de ação.

Okpara, U. T., Stringer, L. C., Akhtar-Schuster, M., Metternicht, G. I., Dallimer, M., \& Requier-Desjardins, M. (2018). A social-ecological systems approach is necessary to achieve land degradation neutrality. Environmental Science \& Policy, 89, 59-66.

Ostrom, E. (2009). A general framework for analyzing sustainability of social-ecological systems. Science (New York, NY), 325(5939), 419-422.

Pacheco, A. A., Neves, A. C. O., \& Fernandes, G. W. (2018). Uneven conservation efforts compromise Brazil to meet the target 11 of convention on biological diversity. Perspectives in Ecology and Conservation, 16, 43-48.

Pareyn, F. G. C. (2010). Os recursos florestais nativos e a sua gestão no estado de Pernambuco - o papel do manejo florestal sustentável. In M. A. Gariglio, E. V. S. B. Sampaio, L. A. Cestaro, \& P. Y. Kageyama (Eds.), Uso Sustentável e Conservação dos Recursos Florestais da Caatinga (pp. 99-115). Brasília-DF: Serviço Florestal Brasileiro.

PBL (2014). How sectors can contribute to sustainable use and conservation of biodiversity. CBD Technical Series, vol. 79. The Hague: PBL Netherlands Environmental Assessment Agency.

Pernambuco. (2009). Lei no 13.787, de 08 de junho de 2009: Law that establishes the State System of Protected Areas (SEUC).

Pernambuco. (2012). Decreto no 38.133, de 27 de abril de 2012: Decree that creates the Ecological Station Serra da Canoa.

PETCON. (2010). Programa de Manutenção das Áreas de Reserva Legal dos Projetos Irrigados de Itaparica no Lado Pernambucano. Companhia Hidroelétrica do São Francisco (CHESF).

Petersen, P. F., \& Silveira, L. M. (2017). Agroecology, public policies and labor-driven intensification: Alternative development trajectories in the Brazilian semi-arid region. Sustainability, 9(4), 535.

Reyers, B., Biggs, R., Cumming, G. S., Elmqvist, T., Hejnowicz, A. P., \& Polasky, S. (2013). Getting the measure of ecosystem services: A social-ecological approach. Frontiers in Ecology and the Environment, 11(5), 268-273.

Riegelhaupt, E. M., \& Pareyn, F. G. C. (2010). A questão energética e o manejo florestal da Caatinga. In M. A. Gariglio, E. V. S. B. Sampaio, L. A. Cestaro, \& P. Y. Kageyama (Eds.), Uso Sustentável e Conservação dos Recursos Florestais da Caatinga (pp. 65-75). Brasília-DF: Serviço Florestal Brasileiro.

Riegelhaupt, E. M., Pareyn, F. G. C., \& Gariglio, M. A. (2010). O manejo florestal como ferramenta para o uso sustentável e conservação da Caaatinga. In M. A. Gariglio, E. V. S. B. Sampaio, L. A. Cestaro, \& P. Y. Kageyama (Eds.), Uso Sustentável e Conservação dos Recursos Florestais da Caatinga (pp. 349-367). Brasília-DF: Serviço Florestal Brasileiro.

Rodorff, V., Araújo, G., Gomes, E., Köppel, J., Siegmund-Schultze, M., \& Sobral, M. (2013). Driving forces and barriers for a sustainable management of the Itaparica reservoir region: Basic milestones towards a constellation analysis. In G. Gunkel, J. Silva, \& M. Sobral (Eds.), Sustainable management of water and land in semiarid areas (pp. 254-268). Recife-PE: Federal University of Pernambuco.

Rodorff, V., Steinmetz, L., Mertens, J., Siegmund-Schultze, M., \& Köppel, J. (2018). Applying Bayesian networks to evaluate small-scale farmers' perceptions of native reforestation practices in Brazil's Caatinga biome. Regional Environmental Change, 7, 1983-1997.

Rogers, K. H., Luton, R., Biggs, H., Biggs, R., Blignaut, S., Choles, A. G., et al. (2013). Fostering complexity thinking in action research for change in social-ecological systems. Ecology and Society, 18(2), 31.

Rylands, A. B., \& Brandon, K. (2005). Brazilian protected areas. Conservation Biology, 19(3), 612-618.

Sampaio, E. V. S. B. (2010). Características e potencialidades. In M. A. Gariglio, E. V. S. B. Sampaio, L. A. Cestaro, \& P. Y. Kageyama (Eds.), Uso Sustentável e Conservação dos Recursos Florestais da Caatinga (pp. 29-48). Brasília-DF: Serviço Florestal Brasileiro.

Santos, J. C., Leal, I. R., Almeida-Cortez, J. S., Fernandes, G. W., \& Tabarelli, M. (2011). Caatinga: The scientific negligence experienced by a dry tropical forest. Tropical Conservation Science, 4(3), 276-286.

Schäfer, M., \& Kröger, M. (2016). Joint problem framing in sustainable land use research: Experience with Constellation Analysis as a method for inter- and transdisciplinary knowledge integration. Land Use Policy, 57, 526-539. 
Schulz, C., Koch, R., Cierjacks, A., \& Kleinschmit, B. (2017). Land change and loss of landscape diversity at the Caatinga phytogeographical domain: Analysis of pattern-process relationships with MODIS land cover products (2001-2012). Journal of Arid Environments, 136, 54-74.

SEMAS. (2012). PE cria $2^{a}$ reserva florestal do semiárido e lança o 'Caatinga Sustentável'. http://www. semas.pe.gov.br/web/semas/exibir_noticia?groupId=709017\&articleId=2352325\&templateId $=2386863$. Accessed 4 April 2018.

SEMAS, \& UNIVASF. (2014). Refúgio de Vida Silvestre Tatu-bola, Petrolina, Lagoa Grande e Santa Maria da Boa Vista Pernambuco: Proposta para Discussão (Atualizada). http://www.cprh.pe.gov.br/ ARQUIVOS_ANEXO/Proposta UC Tatu-Bola_FINAL P.pdf. Accessed 4 May 2018.

Seppelt, R., Beckmann, M., Ceausu, S., Cord, A. F., Gerstner, K., Gurevitch, J., et al. (2016). Harmonizing biodiversity conservation and productivity in the context of increasing demands on landscapes. BioScience, 66(10), 890-896.

Shiki, S. (2010). Política agrária e conservação da biodiversidade no Brasil. Estudos Sociedade e Agricultura, 18(2), 288-316.

Siegmund-Schultze, M. (Ed.). (2017). Guidance manual: A compilation of actor-relevant content extracted from scientific results of the INNOVATE project. Berlin: Universitätsverlag der TU Berlin.

Siegmund-Schultze, M., Köppel, J., \& Sobral, M. C. (2018a). Unraveling the water and land nexus through inter- and transdisciplinary research: Sustainable land management in a semi-arid watershed in Brazil's Northeast. Regional Environmental Change, 7, 2005-2017.

Siegmund-Schultze, M., Rodorff, V., Köppel, J., \& Sobral, M. C. (2015). Paternalism or participatory governance? Efforts and obstacles in implementing the Brazilian water policy in a large watershed. Land Use Policy, 48, 120-130.

Siegmund-Schultze, M., Sobral, M. C., Alcoforado de Moraes, M. M. G., Almeida-Cortez, J. S., Azevedo, J. R. G., Candeias, A. L., et al. (2018b). The legacy of large dams and their effects on the water-land nexus. Regional Environmental Change, 7, 1883-1888.

Silva, J. A. A. (2008). Potencialidades de florestas energéticas de Eucalyptus no pólo gesseiro do AraripePernambuco. Anais da Academia Pernambucana de Ciência Agronômica, 5+6, 301-319.

Silva, T. C., Ramos, M. A., Schwarz, M. L., Alvarez, I. A., Kill, L. H. P., \& Albuquerque, U. P. D. (2014). Local representations of change and conservation of the riparian forests along the São Francisco River (Northeast Brazil). Forest Policy and Economics, 45, 1-12.

Silveira, L., Sollmann, R., Jácomo, A. T. A., Diniz Filho, J. A. F., \& Tôrres, N. M. (2014). The potential for large-scale wildlife corridors between protected areas in Brazil using the jaguar as a model species. Landscape Ecology, 29(7), 1213-1223.

Soares-Filho, B., Rajão, R., Macedo, M., Carneiro, A., Costa, W., Coe, M., et al. (2014). Cracking Brazil's forest code. Science (New York, NY), 344(6182), 363-364.

Souza Júnior, C. B., Siegmund-Schultze, M., Köppel, J., \& Sobral, M. C. (2017). Sinais de um problema crônico: A governança hídrica carece promover os comitês de bacias, coordenar planos e gerir informações. Revista Ambiente e Agua, 12(6), 1054-1067.

Souza, J. M., Rozendo, A. S., Araújo, E. P., Almeida, M. V. A., \& Luna, N. A. (2014). Estudo sobre reflexões e ações educacionais relacionadas ao bioma Caatinga no Cariri Paraibano. V Congresso Brasileiro de Gestão Ambiental Belo Horizonte/MG - 24 a 27/11/2014.

Turnheim, B., Berkhout, F., Geels, F., Hof, A., McMeekin, A., Nykvist, B., et al. (2015). Evaluating sustainability transitions pathways: Bridging analytical approaches to address governance challenges. Global Environmental Change, 35, 239-253.

UNCCD. (2016). Land in balance: The scientific conceptual framework for land degradation neutrality $(L D N)$. Science-Policy Brief, vol. 02. Bonn, Germany: United Nations Convention to Combat Desertification (UNCCD).

Vieira, F. A. S., Bragagnolo, C., Correia, R. A., Malhado, A. C. M., \& Ladle, R. J. (2018). A salience index for integrating multiple user perspectives in cultural ecosystem service assessments. Ecosystem Services, 32, 182-192.

Williams, K. W., \& Tai, H.-S. (2016). A multi-tier social-ecological system analysis of protected areas comanagement in Belize. Sustainability, 8, 104.

Zhang, Q., Prouty, C., Zimmerman, J. B., \& Mihelcic, J. R. (2016). More than target 6.3: A systems approach to rethinking Sustainable Development Goals in a resource-poor world. Engineering, 2, 481-489.

Publisher's Note Springer Nature remains neutral with regard to jurisdictional claims in published maps and institutional affiliations. 